\title{
Entrepreneurial Orientation, Business Development Services, Business Environment, and Performance: A Critical Literature Review
}

\author{
Dr. Washington O. Okeyo, PhD \\ Deputy Vice-Chancellor and Senior Lecturer, \\ Management and Leadership, School of Management and Leadership, \\ The Management University of Africa, Kenya \\ Dr. James M. Gathungu, PhD, CPS (K), Senior Lecturer, \\ Strategy and Entrepreneurship, Department of Business Administration, \\ School of Business, University of Nairobi, Kenya \\ Prof. Peter K'Obonyo, PhD, Professor, \\ Management, Department of Business Administration, \\ School of Business, University of Nairobi, Kenya
}

doi: 10.19044/esj.2016.v12n28p188 URL:http://dx.doi.org/10.19044/esj.2016.v12n28p188

\begin{abstract}
The role of entrepreneurial orientation in firms has been a major area of interest to many scholars in the past. Entrepreneurially oriented firms are innovative, calculated risk-takers, and proactively reach markets ahead of their competitors. This paper examines the role of business development services, internal and external business environments on the relationship between entrepreneurial orientation and firm's performance. The article is a theoretical discourse and uses literature from secondary sources in the analysis. The paper finds that past studies conceptualized entrepreneurial orientation as a three factor single-dimensional model and a five factor multidimensional model. Studies using the three factor model have reported different results to those adopting the five factor approach. This has led to inconsistencies in the empirical results of entrepreneurial orientation on firm's performance. This article also finds that business development services play a mediating role in the entrepreneurial orientation and performance relationship, and that external environment moderates this relationship. However, the paper finds no role of internal environment in the EO-firm's performance relationship. The paper concludes that the link between entrepreneurial orientation and performance is still a worthy area for further study since contradictions still exist in empirical studies. This study recommends that future studies can use a contingency framework to focus on how other factors are likely to affect this relationship.
\end{abstract}


Keywords: Entrepreneurial Orientation, External Business Environment, Internal Environment, Business Development Services, Firm’s performance

\section{Introduction}

Firm's performance in Kenya has been an area of concern to business owners and the government for a long time. During pre and post independence period, business ownership was basically dominated by foreigners. Business ownership favoured colonialists and the Asians who came to the country as labourers to construct railways and roads (Thugge, Ndung'u \& Otieno, 2010). This historical incident denied the indigenous Kenyan the opportunity to freely own and do business in their country. Immediately after independence in 1963, the Kenya government took deliberate steps to encourage indigenous citizens to start and run their own businesses. The first real step towards indigenizing business ownership was the sessional paper number one of 1965 whose primary aim was to promote African Socialism (Kenyatta, 1965). However, the approach to indigenization did not address entrepreneurship which is an important approach to stimulating and nurturing business venture creation and economic development. Even subsequent government policy papers did not adequately address the issue of how entrepreneurship can be used to spur business ownership among Kenyan citizens. Furthermore, the lack of appropriate government policy has impeded the up-take of entrepreneurship in Kenya.

Miller (1983) conceptualized entrepreneurship as an important factor in firm's performance in his seminal paper, and he constructed the concept as entrepreneurial orientation (EO). EO is a firm-level behaviour that makes a firm have the propensity to innovate, take risks, and become proactive (Callaghan \& Venture, 2011). Innovation through EO enables firms to develop new products and make radical changes to existing processes and products. Through EO, firms can undertake uncertain and risky investments and proactively reach markets ahead of competitors thereby realizing high returns. EO is an important phenomenon that plays a crucial role in aligning businesses to market demands. As a result, studies have investigated the link between EO and firm's performance making it a popular area of study. Performance is important to many firms and a lot of them seek to maximize shareholder wealth and pay good dividends to their investors through high performance (Odhiambo, 2015). However, studies have returned mixed findings indicating weak and sometimes negative correlation between entrepreneurial orientation and performance.

Consequently, resource management is an important issue in achieving high performance through EO. An approach known as business 
development services (BDS) is said to enable firms optimally deploy their resources. Okeyo (2015:168) citing McVay (2003) refers to BDS as "an array of activities that firms use in managing their operations to enhance efficiency, effectiveness, and improve their performance and competitiveness.” BDS stimulates product development through application of technology; while at the same time, it enables firms to be located near their markets, acquire relevant infrastructure, and adopt pragmatic procurement practices.

Nevertheless, today firms, including those embracing entrepreneurial orientation and BDS, are faced with complexities in business environments. Internal and external environments are most important to businesses. Internal environment determines how quickly a firm recognizes an opportunity and also how fast it seizes that opportunity. A firm's internal environment refers to the setting of an organization in terms of its structure, resources, skills, and capacity to deliver goods and services (Sudarsono, Pratiwi \& Suhendra, 2007). Also, the acquisition of skills and resources is important for a firm to build strong internal capacity and respond to the market demand. On the other hand, external environment represents the business and regulatory community of an organization, and is one of the main contingencies that a firm faces outside its borders (Chathoth, 2002; Thompson, 1967). External environment is not only important as a source of business opportunities, but it can conversely be a major challenge to a firm. Firms operating in dynamic environments with rapid changes can experience uncertain profitability and thus constantly need to search for new opportunities.

Subsequently, these factors may be a source of differences in past empirical studies on EO-performance relationship. Past studies have also identified method of determining EO as another possible cause of differences. While some studies have conceptualized EO as a three factor one-dimensional model comprising of innovation, risk taking, and proactiveness, others have adopted a five factor multidimensional model which are innovation, risk taking, proactiveness, autonomy, and competitive aggressiveness as individual measures of EO. The three factor onedimensional model is the most popular construct for measuring EO (Fatoki, 2012; Pett \& Wolf, 2010). In this model, research measure risk taking, innovation, and proactiveness individually, but aggregates them into a composite indicator of EO in a firm. Studies (Lumpkin \& Dess, 1996; Gartner, 1985) have criticized this approach arguing that it fails to recognize the individual effects of each of the three factors. The criticisms are echoed by, for example, Lumpkin and Dess (1996:137) who upon pioneering the alterative five factor model stated that:

All of these factors-autonomy, innovativeness, risk taking, proactiveness, and competitive aggressiveness may be present when a 
firm engages in new entry. In contrast, successful new entry also may be achieved when only some of these factors are operating. That is, the extent to which each of these dimensions is useful for predicting the nature and success of a new undertaking may be contingent on external factors, such as the industry or business environment, or internal factors, such as the organization structure (in the case of an existing firm) or the characteristics of founders or top managers. Thus, although some prior research suggests that the dimensions of an EO covary (e.g., Covin \& Slevin, 1989), we suggest that autonomy, innovativeness, risk taking, pro-activeness, and competitive aggressiveness may vary independently, depending on the environmental and organizational context.

Thus, this suggests that using different models, one-dimensional or multidimensional, could result in the lack of consistency in measuring EO which may lead to different values or levels of EO in the same firm. Furthermore, using the three factor model fails to address independent variation of autonomy, innovativeness, and risk taking; hence, it does not include pro-activeness and competitive aggressiveness altogether (Lumpkin \& Dess, 1996). These are major possible causes of differences in the EOPerformance relationship. This article investigates the relationship between EO and performance, and attempts to establish if BDS and internal and external environments have any effect on this relationship. Therefore, the article adopts a theoretical review of past literature to examine these relationships. Also, it relies on secondary sources of data for the analysis.

\section{Literature review}

Innovation and risk theories of entrepreneurship and resource based view (RBV) of the firm form the basis of analysis of the link between EO and performance in this article. Knight (1921) pioneered risk theory and viewed entrepreneurship as an adventure characterized by high risk-taking behaviour. Risk theory posits that entrepreneurial firms take risks by borrowing heavily and committing large amounts of resources to finance high-cost uncertain projects in anticipation of high financial returns through introduction of new products into markets and investing in new opportunities (Awang, et al., 2010; Shapiro, 1994). Pursuit of new opportunity investments and introducing new products in markets also fits within the framework of innovation theory.

Schumpeter (1942) pioneered innovation theory, which was also referred to as "creative destruction theory" of entrepreneurship. The theory states that innovation is the act of radical replacement of outdated products with new ones as well as persistent improvement of product and process mechanisms (Tidd, 2006). Innovation is the adoption of product-market and 
technology strategies by investing in research and development (Miller \& Friesen, 2005), and containing competitor risks (Hamel \& Prahalad, 2005). Adopting product-market strategies and investing in research and development (R\&D) give firms competitive advantage through new product or service development and new market entry (Awang, et al., 2010) leading to superior performance.

Innovation and early market entry by entrepreneurial firms however requires resource commitment. Managing resources in a firm is explained within the framework of RBV. Penrose (1959) pioneered RBV as a theory to explain how tangible or intangible resources can help a firm achieve superior performance and competitive advantage. Tangible resources are physical and include for example technology and finances, while intangible resources are nonphysical and include human capital and accumulated organizational knowledge. RBV also suggests that competitive advantage of a firm is primarily determined by how differently a firm applies the bundle of resources at its disposal (Wernerfelt, 1984; Penrose, 1959). Competitive advantage is achieved through differentiated application of valuable, rare, and inimitable resources (Kibui, Gachunga, \& Namusonge, 2014). RBV therefore treats a firm's resources as an essential factor when undertaking entrepreneurial activities. We therefore find it relevant and make use of it in explaining entrepreneurial orientation and performance relationship in this article.

\section{Entrepreneurial orientation}

Entrepreneurial orientation (EO) has been extensively studied for over the last three decades (Wiklund et al., 2009; Morris et al., 2008; Kreiser et al., 2002). Most of these studies are within the disciplines of entrepreneurship and strategic management, and have concentrated on the relationship between EO and performance. Entrepreneurial orientation has proved to be the most preferred term to refer to entrepreneurship among scholars for describing levels of entrepreneurship in firms. Opinion is however divided in literature about the exact definition of entrepreneurial orientation. Earlier definitions include Lumpkin and Dess's (1996) version which refer to EO as processes, that is, the methods, practices, and decisionmaking styles that lead to new entry. More recent definitions of EO are still inconclusive - for example Moreno and Cassilas' (2008:508) definition of EO as "the organizational decision making proclivity favouring entrepreneurial activities.” On the other hand, Yusof, Sandu and Jani (2007) refer to EO as "the set of psychological traits, values, attributes, and attitudes strongly associated with a motivation to engage in entrepreneurial activities”, and Zahra, Sapienza, and Davidsson's (2006) definition of EO as the rules and norms used for decision making. 
Despite inconsistencies in defining EO, previous studies have generally regarded $\mathrm{EO}$ as the most appropriate determinant of entrepreneurship (Piirala, 2012; Wales, Monsen \& McKelvie, 2011; Rauch, Wiklund, Lumpkin, \& Frese, 2009; Wiklund \& Shepherd, 2005). A substantial number of studies have found that EO has a positive effect on firm's performance (Pett \& Wolff, 2010; Covin \& Slevin, 1989). In addition, Lumpkin and Dess (1996) suggest that EO gives firms competitive advantage. In other words, possessing higher levels of EO enables firms to identify and seize opportunities quicker than non-entrepreneurial firms (Covin \& Slevin, 1991). Subsequently, it also enables firms to beat their rivals in the race to the market place. Thus, firms with high EO tend to perform better than those having lower EO levels.

\section{Operationalizing and measuring entrepreneurial orientation}

EO emanated from Miller's (1983) seminal work following ideas from earlier scholars (Schumpeter, 1942; Kirzner, 1973; Knight, 1921). Interest in $\mathrm{EO}$ as a variable has gained momentum in management and research, especially in the fields of economics, psychology, and strategic management (Fatoki, 2012; Lumpkin \& Dess, 2001; 1996; Covin \& Slevin, 1989). Given the fundamental differences in these disciplines, each study has viewed EO from its own different perspective. This has led to a diversity of conceptual developments of EO which have made it difficult for a common approach in conceptualizing EO to emerge. Economists have viewed EO as the process which combines different factors of production that is, land, labour, and capital to increase a firm's performance (Miller, 1983; Schumpeter, 1934).

Based on this, two main constructs are presented in literature for operationalizing EO.

The first one pioneered by Miller (1983), configures EO as a three factor one-dimensional model consisting of innovation, risk taking, and proactiveness. In this configuration, Miller (1983) argued that entrepreneurial organizations have to engage in risky ventures, be innovative, and should take the lead in reaching their markets (Covin \& Slevin, 1989). The point behind this configuration is that for an organization to be considered entrepreneurial, all the three factors, that is, risk taking, proactiveness, and innovativeness have to be in practice. His argument is that an organization which simply changes its technology or product line through imitation and not by taking any risks cannot be regarded to be entrepreneurial (Kusumawardhani, McCarthy, \& Perera, 2009).

The second construct attributed to Lumpkin and Dess (1996), treats EO as a five factor multidimensional model having competitive aggressiveness and autonomy as additional dimensions to Miller's (1983) 
model. When introducing this construct, Lumpkin and Dess (1996) used the term competitive aggressiveness to signify Miller's (1983: 771) notion of "beating competitors to the punch." In their view, how a firm responds to threats is important in addition to seizing opportunities. The dimension of autonomy according to the authors represents strong leadership by creative individuals who act freely without much restriction. Contrary to Miller (1983) assertion that all EO dimensions must exist for a firm to be termed entrepreneurial, Lumpkin and Dess (1996) held the view that it is not necessary for all five EO dimensions to be present.

\section{Risk taking by firms}

The contemporary dynamic business environment characterized by diversity and complexity subject firm's managers to making business decisions under uncertainty. However, making decisions in such circumstances requires an understanding of the situation to enable a firm take moderate and calculated risks to limit the firm's exposure (Morris, Kuratko, \& Covin, 2008). Risk taking is the tendency of a firm to borrow heavily, commit substantial amount of resources to projects whose returns are not known, and make entry into new unexplored markets (Walter, Auer, \& Ritter, 2006; Lyon, Lumpkin, \& Dess, 2000). Research (Lumpkin \& Dess, 1996) has tended to link risk taking to entrepreneurship since the original concept involved the assumption of risk. Therefore, most studies have treated risk taking as a critical measure of $\mathrm{EO}$ when determining the extent of entrepreneurship in a firm.

Dess and Lumpkin (2005) identified three main types of risks faced by organizations, that is, business risk, financial risk, and personal risk. Business risks are organization-wide and entail actions such as making entry into new markets or the tendency to use untested technologies (Piraala, 2012; Dess \& Lumpkin, 2005). New market entry as well as using unproven technologies may give a firm competitive advantage in the marketplace. Financial risks on the other hand involve committing a firm's resources towards growth initiatives (Baird \& Thomas, 1985). Thus, this could take the form of borrowing or liquidating assets to finance expansion opportunities with uncertain outcomes (Avlonitis \& Salavou, 2007). Firms taking such financial risks may experience rewards in form of substantial returns or significant losses. Lastly, high personal risk appetite of a senior manager of a firm may make such a firm to engage in risky behavior (Hughes \& Morgan, 2007). In addition to the manager personally bearing the consequences of such risks, the firm could also suffer from those risks in case of failure. 


\section{Innovation in firms}

Rapid changes in global markets have resulted in rising competition and erosion of value add and the effectiveness of organizations' products and services (Gunday et al., 2007). Innovativeness is one of the fundamental instruments of firm strategies to develop new and enhance existing processes, products, and services to penetrate markets, expand market share, and give a firm competitive advantage in response to these changes. Innovativeness refers to a firm's behavior to generate new ideas leading to new or improved processes, products, or services (Rauch, et al., 2009). Innovativeness is also related to creativity which is a source of ideas that can lead to innovation of products, services, processes, markets or technology (Landstrom, 2005). Innovation was first recognized by Schumpeter (1942) when he equated it with "creative destruction." In his view, creative destruction is the process in which wealth creation destroys existing market structures by introducing new goods or services which shift resources from existing to new firms, thus giving new firms growth advantage. Lumpkin and Dess (1996) supported this view when he argued that it is the entrepreneur who initiates creative destruction process making innovation a fundamental determinant of EO.

Covin and Slevin (1989) developed a nine-item scale that has been dominantly used to measure three EO (Miles \& Arnold, 1991; Milovanovic \& Wittine, 2014). In this scale, innovativeness is measured by published information on enhancements made to product lines or upgrades done to a firm's technology (Lyon, Lumpkin, \& Dess, 2000). Arguing that product innovation should be the only indicator of entrepreneurship in a firm, Wiklund (2006) suggested a number of new products introduced into new or existing markets by a firm as the sole measure of innovative practices. Therefore, Giudici and Reinmoeller (2013) demonstrated this when they suggested a number of new products developed or new markets entered by an organization as measures of innovative practices.

\section{Proactiveness to market}

In the current competitive business environment, firms may gain first-mover advantage in the marketplace by introducing new processes or products ahead of competitors (Lumpkin \& Dess, 2001). The tendency to be forward-looking and to become a first-mover indicates a firm's proactiveness. Miller (1983) hinted an entrepreneurial firm as one of the quickest in introducing products or services. Later, Lumpkin and Dess (1996: 146) defined proactiveness as "taking initiative by anticipating and pursuing new opportunities related to future demand and by participating in emerging markets." Hughes and Morgan (2007) thereafter argued that a firm's 
proactiveness is determined by how aware and responsive it is to market signals.

Proactiveness is also linked to opportunity recognition. Kropp et al. (2008) argued that firms that identify and evaluate new opportunities and monitor trends in markets are regarded as proactive. Studies have argued that proactive firms introduce new products in the market ahead of competitors (Kusumawardhani, McCarthy \& Perera, 2009; Venkatraman, 1989). Past research (Lumpkin \& Dess, 1996) has operationalized firm-level proactiveness as a number of new products in a firm. Covin and Slevin's (1989) scale measures proactiveness as the management's perception of a firm's tendency towards the market.

\section{Competitive aggressiveness in firms}

Competitive aggressiveness was introduced in Lumpkin and Dess's (1996) article to emphasize Miller's (1983) notion of "beating competitors to the punch.” Although this view posits that firms mainly win customers over their competitors through proactive innovation, literature argues that competitive aggressiveness is distinct from proactiveness. Lumpkin and Dess (1996:139) reasoned that competitive aggressiveness is "the type of intensity and head-to-head posturing that new-entrants often need to compete with existing rivals." They clarify that competitive aggressiveness is "the intensity of a firm's efforts to outperform industry rivals (Lumpkin \& Dess, 2001:433). They argue that competitive aggressiveness involves a strong offensive posture directed at overcoming competitors..." Lyon, Lumpkin, and Dess (2000:1056) define competitive aggressiveness as "the tendency of firms to assume a combative posture towards rivals and to employ a high level of competitive intensity in attempt to surpass rivals.”

In the past, how firms relate to competitors has been used to measure competitive aggressiveness especially in regard to trend and demand patterns in established markets. In other words, competitive aggressiveness may be described as the number of actions taken by a firm and the time it takes a firm to respond to a competitor's action. By using this approach, studies have determined that rapid response (Chen \& Hambrick, 1995; Chen \& Miller, 1994) and total number of actions (Young, Smith \& Grimm, 1996) are good measures of competitive aggressiveness. This approach is consistent with Porter (1985) who earlier stated that competitive aggressiveness is about competing for demand.

\section{Autonomy in work environments}

Literature (Kusumawardhani, McCarthy, \& Perera, 2009) argue that giving independence to everybody in an organization is likely to enhance their entrepreneurial behavior and improve performance. If a firm 
encourages individuals or a team to bring forward and carry through to completion an idea or view, the firm can benefit from independent spirit necessary for pursuing entrepreneurial opportunities. Autonomy which refers to "the ability and will to be self-directed in the pursuit of opportunities" is an entrepreneurial act (Lumpkin \& Dess, 1996). According to Coulthard (2007), autonomy in EO flourishes when independent minded people leave comfortable positions to pursue novel ideas. Autonomy is also a significant factor for improving performance in existing firms.

Evidence from past research indicates that autonomy in firms may functionally depend on firm size, management style, or ownership. Lumpkin and Dess (1996) argue that where the owner-manager is the decision maker, the right of ownership determines the level of autonomy. In this case, autonomy is determined by the level to which leadership is centralized and the frequency at which managers delegate authority. In large firms, autonomy refers to a firm's restructuring through delegation of authority and reduction of vertical structures in management. Autonomy has been demonstrated in some firms by granting freedom and encouraging organizational players to exercise it. According to Lumpkin and Dess (1996), this involved the use of champions to promote entrepreneurial activity. These champions protect new idea creators from the undesirable judgment and treatment of the organization and from the possible resource constraints.

\section{Business development services}

Studies show that reliance on own resources alone limits a firm's ability to effectively pursue their goals and create competitive advantage (Gaudici, 2013). Firms should broaden their sphere to access their markets, information sources, infrastructure, supplies, training, and develop their products. Therefore, governments and development agencies have for a long time supported firms in various countries to leverage their internal capabilities (Atieno, 2012). This initiative is anchored on assistance that leads to poverty alleviation and spur economic growth (Fatoki, 2012). Business development approach known as BDS has been used to provide this support. BDS initially meant providing financial needs through microfinance services to organizations. However, this was later broadened to focus on a firm's managerial and operational needs (McVay \& Miehlbradt, 2002). At inception, BDS concentrated on the supply of financial services subsidized by donor agencies and governments to a few organizations. The focus shifted to a market rich in BDS with non-financial services to many firms. BDS later expanded to include marketing, information sources, infrastructure, policy reform, and supplies (Miehlbradt \& McVay, 2003). The ability of BDS to boost the managerial and the operational needs of a firm have potentials for positive firm effects (Steel \& Webster, 2001). 
BDS helps firms to enter markets ahead of competitors. Studies indicate that firms with ubiquitous market presence have an advantage over their competitors. Frequent interfacing with customers and consumers allows firms to know market gaps, making them attend to customers ahead of their competitors (Price, Stoica \& Boncella, 2013). JP Morgan Chase (2013) found that regular interaction helps firms to develop relationships with their customers and gain from opportunities arising from information exchange which enables firms to develop products to satisfy their customer's needs. Similarly, such firms enjoy infrastructure related benefits such as warehouses, incubation services, roads, communication, and ICT systems (Grimaldi \& Grandi, 2005; Patton, Warren et al., 2009).

According to UNDP (2004), infrastructure is important for new business incubation. Dee et al. (2011) argues that firms require incubation facilities during phenomenal growth, but lack the necessary capital. Heckits and Dilts (2004b) add that incubation gives firms credibility by association and shared access to professional facilities. Incubation offers firms business support and coaching opportunities, and access to additional resources and talents such as finance and legal help. Good roads networks, ICT systems, and networks permit firms to move and deliver their goods and services to the markets faster than their competitors. Thus, firms with access to infrastructure facilities for warehousing, business incubation, communication, and market reach enjoy competitive advantage which could enhance their performance.

BDS providers enable firms to develop policy and training in advocacy (Brijlal, 2008). The training enables firms to advocate for and develop their policy framework. According to Feinstein (2010), a policy framework defines the boundaries of a firm's activities. This helps to identify benefits and the opportunity costs of a firm's decisions and annual process of resource allocations. Policy enhances a firm's credibility in the eyes of peers and third parties including government, customers, and other interested entities (AEVAL, 2008). Advocacy and policy development enables firms conform to government and industry regulations, and operate within a welldefined framework for the allocation and control of resources. BDS further enables firms to negotiate favourable procurement terms by forming groups for long term and group supply agreements (Hong \& Jeong, 2008). Therefore, these according to Humphrey and Schimtz (1995) have helped firms through bulk purchases and group discounts.

\section{External business environment of a firm}

External environment is as an important factor to firms because it is a threat to their intentions and is a source for opportunities (Johnson \& Scholes, 2002). Threats and opportunities in the external environment 
manifest in the form of different types of risks and uncertainties facing the firm. Risks are exacerbated by environmental complexity and dynamism which can significantly impede the success of a firm. According to Goll and Rasheed (2004), many factors which make up the external environment and their complexity, in terms of numbers and dynamism in terms of changes, poses serious risk to the success of firms. External environment is an important source of resources that firms need for its day to day activities.

Prior studies (Emiry \& Trist, 1965; Bourgeois, 1980) have used the contingency approach to develop an appropriate model for the environment. However, this approach which has been dominant especially in strategic management literature gives prominence to environment and how it affects firm's performance. This is evident in the works of, for example, Osborn and Hunt (1974), Dess and Beard (1984), Johnson and Scholes (2002), and Goll and Rasheed (2004). These and other scholars have presented environment as an important factor when formulating strategies to mitigate its effect on a firm's performance. Furthermore, the studies have over time made significant contributions to the body of academic knowledge on the environment both conceptually and empirically.

Several studies have conceptualized external environment in terms of dynamism, complexity, and munificence (Machuki \& Aosa, 2011; Johnson \& Scholes, 2002; Dess \& Beard, 1984). The dimensions have been used to analyze the effect of external environment on the link between entrepreneurial orientation and performance in recent studies (Okeyo, Gathungu, \& Kobonyo, 2014; Goll \& Rasheed, 2004). These studies found that external environment plays both direct and indirect roles in this relationship. In addition, the studies suggested more investigation on the indirect effect of the environment on performance. Environmental dynamism refers to severity levels of changes in the external environment and their unpredictability (Goll \& Rasheed, 2004). Uncertainty, volatility, and highvelocity nature of external environment exert unpredictable changes to firms (Machuki \& Aosa, 2011). Dynamism includes the pace at which market players like customers and competitors change and innovate; also, it refers to the unpredictability and uncertainty of their actions and behaviour.

Change and innovation is critical to a firm's orientation towards growth and success. Extant literature (Gathungu, Aiko \& Machuki, 2014) argues that rapid changes in the external environment increases uncertainty and reduces the ability of firms to predict such changes. Literature (Porter, 1980) has established that rapidly changing environments is a common occurrence in many industries. Firms operating in dynamic environments therefore need to adjust to environmental changes for their survival. Also, less dynamic environments are friendlier to organizations. In such environments, elements of the external environment such as economic 
conditions are relatively more stable (Johnson \& Scholes, 2002). Therefore, these conditions are normally the characteristics of developed economies, but it manifest in a mature and in a well-established industries in developing economies as well. Stable environments thus render firms unable to adjust because they lack rapid changes that could have a negative impact on the growth and success of firms.

External environment is an important source of resources needed for firm's growth and success (Pfeffer \& Salancik, 1978). Munificence of resources determines whether firms can innovate and compete in the marketplace. Goll and Rasheed (2004) citing Aldrich (1979) define munificence as the ability of an environment to support the growth of a firm. In another study, Castrogiovanni (1991) argue that munificence manifests as capacity, growth or decline, and opportunity or threat. Capacity means resource availability within a firm; growth or decline refers to changes in capacity; and opportunity or threat means dormant or undiscovered capacity. When environment is non-munificent or hostile, firms are more conservative due to resource scarcity (Goll \& Rasheed, 2004). Conservativeness causes firms to cut down on spending in non-essential areas such as research and development and the results of a negative impact on innovation (Allegre \& Chiva, 2009). Firms operating in such environments can commit illegal acts by engaging in unlawful or unethical practices while attempting to acquire the necessary resources. On the contrary, munificence of resources in industry or environment enables firms to achieve better returns from their investments. This affords them the opportunity to get involved in non-core business practices such as social and philanthropic engagements.

Complexity of the environment has featured in many past studies as an important factor affecting firms (Goll \& Rasheed, 2004; Aldrich, 1979; Sharman \& Dean Jr., 2001). Complexity refers to the number of issues in the external environment and their differences that a firm needs to deal with (Machuki \& Aosa, 2011). Mintzberg's (1979) asserted that "the significance of complexity is in its implications for comprehensibility of the work to be performed in an organization” (Sharman \& Dean Jr., 2001:685). Thus, complexity originated from the works of Dess and Beard (1984). These works operationalized Aldrich's (1979) environmental construct into a three factor model having complexity, dynamism, and munificence as the main dimensions (Sharman \& Dean Jr., 2001). Dess and Beard (1984), Aldrich (1979), and Mintzberg (1979) found that a number of factors combine to form complexity. They identified geographic concentration, sophistication of knowledge, and processing of required information as some of the major factors.

Concentration of firms in one geographical area is an important factor that may impact their success. Concentration leads to intense competition 
and affects demand for a firm's products and services (Sharman \& Dean Jr., 2001). Knowledge sophistication, another aspect of complexity, is given prominence by Johnson and Scholes (2002) when they reason that the knowledge of the prices of commodity and currency trading is a key resource which gives firms competitive advantage gained from competences in higher-quality information than that of competitors. This makes other firms to actively gather market information to acquire the necessary intelligence (Sharman \& Dean Jr., 2001). It is evident that concentration, possession of required sophisticated knowledge, and ability to process required information has an impact on comprehensibility. This means that complexity is a crucial environmental factor likely to affect firms.

\section{Internal business environment}

Internal environment is an integral part of a firm's operating environment and is the key to the decision making process and the achievement of a firm's objectives. Internal environment comprises of all elements within an organization such as management, employees, structure, and culture (Kinyua-Njuguna, Munyoki, \& Kibera, 2014). In addition, other analyses have included the age and size of the organization (Sharifi \& Charrakh, 2011; Farhangi \& Safarzadeh, 2005; Sheaff et al., 2003). Internal environment is defined as the forces operating internally within an organization, but having a direct influence on a firm's performance. Freeman and Reed (2006) enumerated some of these forces as demographics such as size, age, institutional inter-linkages, objective, financial resources, information, knowledge, and goals of the company as well as employee skills. Despite variations in operationalization of internal environment, its role as a key driver of a firm's success has received minimal dispute. McKinsey's 7S framework is one of the most widely used models in conceptualizing internal environment (Wilson \& Gilligan, 1997). The 7S framework is made up of seven interdependent elements which are broadly classified as "soft" or "hard". The soft elements consist of shared values, skills, style, and staff, while the "hard" ones are strategy, structure, and systems.

Shared values consist of many variables that constitute a firm's belief system. Marvis et al. (2010) refer to shared values as traits, behaviour, and characteristics that a firm believes in. These include primarily the vision and mission of the organization (Garbrah \& Binfor, 2013). Firms competing in business must have an appropriate vision and mission to align their activities with their desired future for survival (Wilson \& Gilligan, 2003). Absence of vision and mission indicates lack of a well-defined strategic direction and intellectual framework. Firms without shared values find it difficult to achieve their future desires due to lack of appropriate conceptual map. A 
firm's success is affected by staff in terms of its employee base including the staffing plans and how talent is managed. Studies on firm staffing posit that in the current fast changing environment, firms require adequate staff with relevant skills to respond to their business needs (Miri, Rangriz \& Sabrikaran, 2011). According to Garbrah and Binfor (2013), a fast changing environment increases the need to recruit the right staff, plan for their development, manage their talent, and give a firm reliable workforce. Subsequently, improving employee's skills and knowledge through training is an essential part of staff development. This implies that inadequate staff management systems and procedures can lead to non-achievement of a firm's objectives.

A firm's structure is a key issue in organizations. Structure has a bearing on a firm's internal environment and strategy. In many ways, strategy is the counter hostility measure that represents a well-planned and organized process towards a firm's future. Strategy has been commonly used to align resources and capability to become effective in the market. Johnson and Scholes (2002:10) defined strategy as the "direction and scope of a firm over the long-term which gives advantage for the firm through resource configuration in a changing environment and fulfilling stakeholder expectations." The establishment of future direction for a firm is a key issue in strategic making process and the success of the firm. Literature argues that strategic plans that emanate from an inclusive process involving staff and other stakeholders have a competitive edge; hence, it is crucial for a firm's success (Porter, 1985).

Establishing this direction however requires a well thought out and designed firm structure (Farhangi \& Safarzadeh, 2005). Structure includes roles and responsibilities together with accountability relationships needed to run a firm. Popular firm structures have board of directors, executive management, management, and staff. Studies have found that structures influence the degree and way in which firms respond to environmental changes and stakeholder expectations (Papasolomou, 2006). Highly vertical structures impede information flow thereby reducing the speed of decision making (Sharifi \& Charrakh, 2011). Conversely, horizontal or less vertical structures speed up the decision making process in a firm. The system component of the 7S model refers to the business and technical infrastructural framework that employees need to accomplish their tasks on a day-to-day basis (Garbrah \& Binfor, 2013). These include, for example, management policies, procedures, and functional information systems (Tom \& Taves, 2004). Studies focusing on internal environment have established that firms with weak or no systems risk failure to execute tasks in an orderly manner. This is likely to have a negative impact on the achievement of their objectives (McKelvie \& Davidson, 2009). 


\section{Firm's performance}

Performance aims to determine how a firm achieves an objective goal or standard. In business research, many definitions depend on the discipline or area of study. Wu (2009) relates performance to the value that customers and other stakeholders derive from a firm. Performance means achieving stakeholder interests in a more superior way than competitors. Therefore, having superior performance requires an organization to achieve its set of objectives in an effective and efficient manner (Gathungu, Aiko \& Machuki, 2014). Efficiency and effectiveness have become popular measures and an array of manufacturing, finance, and marketing measures has been used in the past. In manufacturing, authors (Kombo, K’Obonyo, \& Ogutu, 2015; Atalay, Anafarta, \& Sarvan, 2013; Wu, 2009) have advocated for measuring five key dimensions consisting of reliability, quality, product price or cost, and flexibility to determine performance. The intention is to use a multidimensional approach that takes into account a combination of different factors that affect performance, thus incorporating the interest of both stock and stakeholders.

Operationalizing performance has remained a thorny issue in academic research till date. Performance is usually regarded as a contextual issue. Therefore, its measurement becomes more a factor of what is being determined and even where and when it is being measured. In business generally, and specific fields such as entrepreneurship, there is a general consensus that the main concern of a firm is performance (Gathungu, Aiko, \& Machuki, 2014). Despite the consensus, there is no agreed measure of performance. According to Odhiambo (2015), past studies have failed to justify their selection of indicators to measure performance and tend to go by tradition. Performance measurement has changed in the last several decades from purely financial indicators.

Within entrepreneurship, the interest is more towards knowing how well the entrepreneurial firm is performing; and hence, it makes more sense to measure performance using indicators relating to activities being performed in a firm. Such activities are normally broadly categorized to be financial or non-financial (Mthanti, 2012). Researchers adopting the financial approach have commonly used some combination of accounting indicators such as sales revenue or growth, profitability, earnings per share, or return on assets (Odhiambo, 2015). The reason behind this selection is based on finance theorists and practitioners who have often argued for maximizing shareholder wealth as the main objective of the firm (Moyer, McGuigan, Rao \& Kretlow, 2011; Van Horne \& Wachowicz, 2009). These authors agree that the combination of indicators are measures of shareholder wealth and hence performance of the firm. 
Non-financial measures used to determine firm performance are evident in balanced score card (BSC) by Kaplan and Norton (2008a, 2008b, 2006a, 2004a, 1992). Consequently, BSC has proved to be one of the most widely used approaches to measuring performance. BSC has financial component and three other performance measures including customer related indicators such as loyalty and on time delivery; internal business processes quality and cycle-time; and learning and growth especially in employee's skills (Iveta, 2012). When introducing BSC as a comprehensive measure of performance, Kaplan and Norton argued that the value from intangible assets is indirect. For example, it is rare that such assets as knowledge and technology impact directly on revenue or profit. Yet, when these and other intangible assets improve, their cause-and-effect relationships during two or more intermediate stages affect financial outcomes (Kaplan, 2010) and, hence, the overall performance.

A review of existing literature indicates diverse approaches used to determine performance of firms (Gathungu \& Aiko, 2014). These studies performance is constructed using multiple dimensions (Carton, 2004; Santos, 2009). This is demonstrated in studies such as Maury (2006) which measured firm performance using both market and accounting indicators. Yet, other studies used asset turnover ratio and book value to market values as single measures of this important variable (Odhiambo, 2015). In other words, there is no known study which has identified a universally accepted single measure of a firm's performance. Neither is there any study that was discovered that has used a preferred model to represent the performance construct (Gathungu \& Aiko, 2014; Santos, 2012).

\section{Entrepreneurial orientation and firm's performance}

In order to establish a direct link between EO and performance, researchers have adopted a variety of methods and approaches to measure both variables. Pett and Wolff (2010) used the framework for the concept developed by Covin and Slevin (1989) in which entrepreneurial orientation was conceptualized as a one-dimensional construct of risk taking, proactiveness, and innovativeness to examine if entrepreneurial orientation had an effect on the performance of SMEs in the U.S.A. The study found a positive and significant relationship between EO and SME performance. Gathenya, Bwisa and Kihoro (2011) measured entrepreneurial orientation in terms of propensity to take risks, innovation and pro-activeness, but in a multidimensional configuration. Furthermore, the study established that only some measures of EO were positively correlated with the performance of firms in Kenya.

Despite these positive results, divergent arguments are common on whether there is a direct effect of entrepreneurial orientation on performance. 
In a study focusing on SME performance in South Africa, Fatoki (2012) found that although entrepreneurial orientation had a positive effect on performance, that effect was not direct as it depended on other conditions. This view concurs with researchers like Kurokawa, Tembo and Willem te Velde (2008) who cited McCormick (1999) that firms clustered together in urban areas in Kenya reported better performance than those in isolation or in remote areas due to access to collective or business development services. Contradictions on the direct link between EO and performance are mainly attributed to how EO is constructed and measured. Miller (1983) pioneered a three dimensional construct to represent entrepreneurial orientation. In this model, Miller strongly suggested that the three dimensions, that is, risk taking, innovativeness, and proactiveness must all co-exist to indicate the presence of EO. In other words, if a firm invests in risky assets but does not innovate or is not proactive or vice versa, such a firm is not considered entrepreneurial. Later, Lumpkin and Dess (1996) added competitive aggressiveness and autonomy, increasing the number of dimensions to five. In this five dimensional model, the two scholars argued that anyone or combination of the five dimensions could represent the presence of entrepreneurial orientation, a view which contradicted that of Miller (1983).

Another point of difference noted in literature is the measurement of the variables. Different studies have not only used varying number of items for each dimension, but also have varying measurement scales. For example, scholars use Likert type scales which vary from five, seven, nine, and even eleven points in their studies. Literature has demonstrated that Likert type scales are the most common (Khandawalla, 1977; Covin \& Slevin, 1989; Pett \& Wolff, 2010). The idea that EO and firm's performance are directly related is therefore a debatable point in entrepreneurship research. Whereas some studies demonstrate that entrepreneurial orientation has a positive and significant effect on performance, others clearly contradict this view. They either indicate non-existence or suggest the need to consider other variables. It is this mixed and inconclusive position which this study finds an important issue for scholars and researchers to investigate among firms in different contexts, other firms, and in the presence of other variables.

\section{Entrepreneurial orientation, business development services, and firm's performance}

The idea that BDS has an effect on firm's performance has been a subject of discussion for many decades especially among the international and development agencies. The World Bank and International Labour Organization have supported studies examining how BDS may be used to improve firm's performance in developing economies. The debate however became popular in academic and business environment in the last decade. 
According to Miehlbradt and McVay (2001), firms need business development services to facilitate production and delivery of their products and services.

From RBV perspective, firms differ in performance not only due to resources possessed, but due to how they use those resources (Penrose, 1959). BDS represents one of the most important resources available to a firm (Okeyo, 2015). An array of research is available that explains the role of BDS on a firm's market access, procurement, product development, and output (Fatoki, 2012; Brijlal, 2008). The decision to be entrepreneurially oriented is a management prerogative that results from internal considerations. Given the wide variation of BDS from sector to sector, and firm to firm, it seems logical to infer that the relationship between EO and firm's performance may change based on the type of BDS that is used. For example, a large amount of research has empirically established BDS-type dependence of performance (Miehlbradt \& McVay, 2001; McCormick, 1999).

Although BDS can be classified in many ways (Okeyo, 2014), the dominant approach in business research uses basic dimensions consisting of market access, infrastructure, policy and advocacy, input supply, training and technical assistance, technology and product development, and alternative financing mechanisms (International Labour Organization, 2003). Some studies have empirically established mediating and moderating role of BDS in a variety of studies on business factors and firm's performance. For example, Okeyo (2015) found that the relationship between business environment and firm performance is mediated by BDS. Effectively, it is likely that BDS mediates the EO and performance link.

\section{Entrepreneurial orientation, internal business environment, and firm's performance}

The ubiquity of internal business environment in firms is argued to be a significant factor in their activities (Kibui, Gachunga, \& Namusonge, 2014; Busienei, K’Obonyo \& Ogutu, 2013). Therefore, this implies that a firm's internal environment is likely to influence how various factors affect performance. Entrepreneurial orientation is presented in extant literature as an important factor in the performance of a firm (Fatoki, 2012; Pett \& Wolff, 2010). How entrepreneurial orientation affects firm performance is therefore likely to be influenced by internal environment. Studies (Gathungu, Aiko \& Machuki, 2014) often argue that the effect of entrepreneurial orientation on a firm's performance is not conclusive, and this effect depends on other factors. Among the imposing factors in a firm are the resources it possesses. Resource based view argues that a firm's performance is determined by the rare, valuable, inimitable, and non-substitutable resources that a firm has. 
Parida, Westerbery, Ylinenpaa, and Roininen (2010) reason that firms that possess resources with these characteristics can secure economic rents by creating strong barriers, hence making them profitable.

However, the ability of firms to acquire and use such resources depends on internal factors. The effect of a firm's internal factors on their performance is articulated in the early conceptual works of Thompson (1967). This early view is based on organizational theories (Williamson, 1985) which explain how firm's performance is affected by the transaction costs of their internal activities. Consequently, research (Miri, Rangriz \& Sabrikaran, 2011; Sharifi \& Charrakh, 2011) established a relationship between internal business environment and firm's performance. Deriving from contingency theory's distinction of internal and external business environment (Thompson, 1967), scholars have focused on how internal factors affect the firm's performance. Studies (Miri, Rangriz \& Sabrikaran, 2011) suggest that vertical structures may slow down information flow as the complexity of such structures could impede the information dissemination. Therefore, this differs from firms with horizontal structures as they are likely to experience higher rate of information flow resulting in faster decision making process. Additionally, the advantages of internal firm's characteristics enable a firm not only to use resources effectively, but also to take more risks, be more innovative, and become proactive, hence enjoy higher status of entrepreneurial orientation. While studies (Gaudici, 2013; Fatoki, 2012; Kroeger, 2007; Davis, 2007) have presented strong arguments for the relationship between entrepreneurial orientation and firm's performance, little work is evident regarding the role of internal environment in this relationship. In other words, internal environment has no influence in the EO performance relationship.

\section{Entrepreneurial orientation, external business environment, and organizational performance}

The effect of entrepreneurial orientation on firm's performance has been a subject of debate in many studies (Pasanen, 2003; Sawyerr, McGee \& Peterson, 2003). Research (Wiklund \& Shepherd, 2005) shows positive results, yet insignificant relationships (Lumpkin \& Dess, 1996). Consequently, other studies (Atuahene-Gima \& Ko, 2001) have found negative correlation. Empirical results are thus inconclusive, suggesting the role of other factors. This confirms the idea that there could be factors that moderate the way entrepreneurial orientation affects firm's performance (Milovanovic \& Wittine, 2014). External environment is among other factors that interact closely with firms and which might moderate this relationship. Sawyerr, McGee, and Peterson (2003) reported that managers can respond to uncertainty by finding information from external sources. By so doing, they 
can influence the financial performance of their firms. This implies that depending on the difficulty with which such resources are obtained from the external business environment, performance may be affected adversely. Adverse effect would be low if the effect of external business environment is less severe. Extant studies in Kenya have analyzed the effect of external business environment on firms and arrive at similar conclusion. For example, Machuki and Aosa (2011) studied firms listed at Nairobi Securities Exchange (NSE). The study found that although external business environment is correlated with performance, its effect is not statistically significant. The study concludes that NSE firms do not perceive the effect of external business environment on their performance as important.

Past studies have examined the moderating role of external business environment on performance. The results vary showing lack of convergence. Milovanovic and Wittine (2014), Goll and Rasheed (2004), and Wiklund and Shepherd (2003) examine the moderating influence of external environment on firm's performance. While Goll and Rasheed (2004) found that highly dynamic environments had a significant moderating effect on firm's performance, Milovanovic and Wittine (2014) found that external environment had no moderating influence on the relationship. Therefore, these arguments in theory and empirical studies suggest that opinions are divided regarding the role of external business environment on firm's performance. Differences could be attributed to several factors such as conceptualization, measurement, and methods of analysis. Whereas some studies (Goll \& Rasheed, 2004) considered only two aspects of external environment that is, munificence, and dynamism, others (e.g. Machuki \& Aosa, 2011) used three aspects comprising complexity, dynamism, and munificence. Despite differences in methods of measurement of the variables, external environment has an effect on the EO - performance relationship.

\section{Conceptual framework for the study}

Literature review reveals gaps in the findings and opinions of past studies. Whereas some views agree that EO has a direct influence on firm's performance, others argue that this relationship is not conclusive and is subject to other factors. This study investigated mediating role of business development services, and moderating effects of internal and external business environment in this relationship as presented in a diagrammatical form in Figure 2.1. 


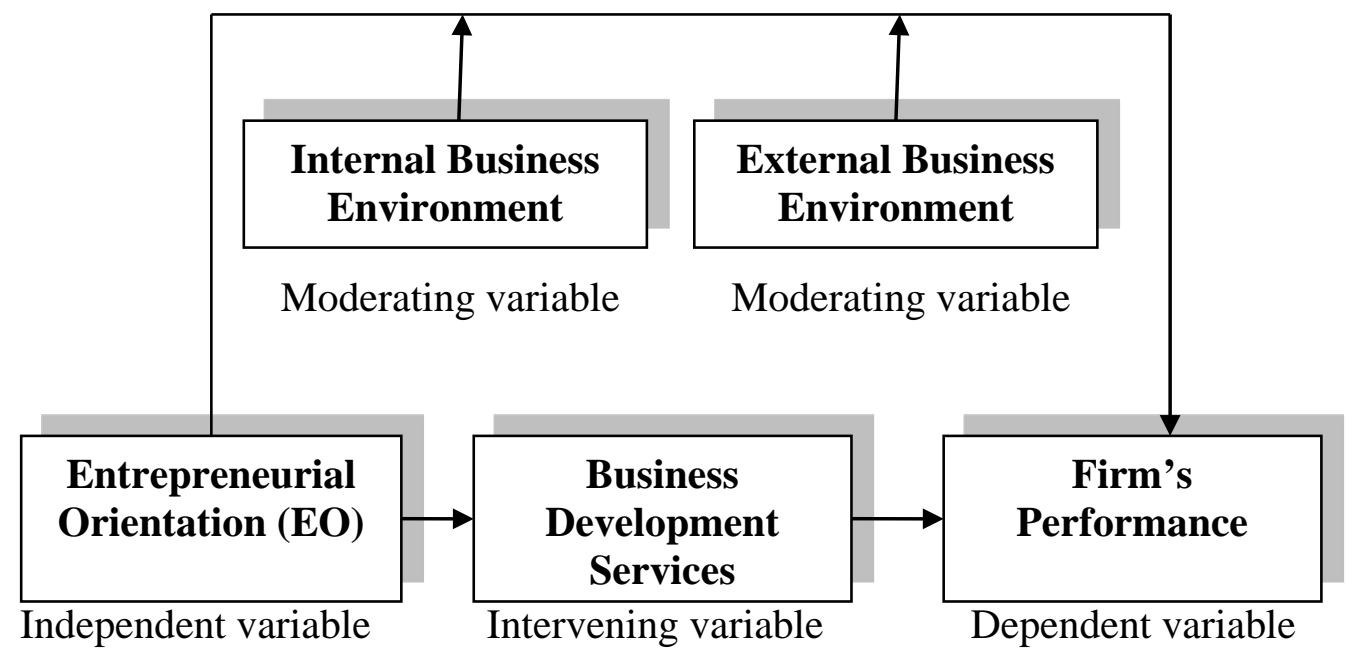

Figure 2.1- Conceptual framework for the study

\section{Methodology}

This paper adopted a qualitative research design which entailed a critical review of literature on the effect of entrepreneurial orientation on firm's performance and the role that business development services, internal environment, and external environment play in this relationship. The rationale for this design was to interrogate views, methods, and findings of authors on the relationships among study variables. Therefore, the study used secondary data obtained from journal articles, books, publications, and conference papers drawn globally. The review mainly used content analysis which were mentioned, and discussions specific to the study variables were identified, analysed, and critiqued.

\section{Conclusion of the study}

This study examined the link between entrepreneurial orientation and firm's performance and the roles of business development services, internal environment, and external environment in this link. The study finds that the effect of entrepreneurial orientation on firm's performance is inconclusive and is still a subject of academic debate. This study also finds that the absence of an agreed single theory of entrepreneurship concept and lack of a single definition of entrepreneurial orientation has caused a great deal of confusion in research. This has led authors to conceptualize and measure entrepreneurial orientation differently and has resulted to the lack of consistency and variations in empirical results from different studies.

Contrary to the general belief that entrepreneurial orientation always has a positive impact on performance, this study established that the effect of 
entrepreneurial orientation on firm's performance is actually mixed. Whereas entrepreneurial orientation is shown in some studies (Fatoki, 2012; Pett \& Wolff, 2010) to have a positive effect on performance, other studies (Rauch, 2009; Kaya \& Seyrek, 2005) have sometimes reported negative or insignificant association between entrepreneurial orientation and firm's performance. Business development services have some role to play in the link between entrepreneurial orientation and firm's performance. This is evident in studies (Okeyo, 2015; Okeyo, 2013; Fatoki, 2012; Brijlal, 2008) which found intervening and sometimes moderating roles of business developments services on a firm's performance. Therefore, firms with entrepreneurial orientation that use business development services are more likely to experience superior performance.

No evidence is found in literature for the moderating effect of internal environment on the relationship between EO and performance. The study, however, finds that external environment plays a moderating role in the entrepreneurial orientation - performance link. Therefore, this conclusion finds support in literature (Goll \& Rasheed, 2004; Okeyo, Gathungu, \& Kobonyo, 2014) which report that external environment moderates performance in firms. This paper recommends that future studies can use a contingency framework to focus on how other factors are likely to affect this relationship. Thus, the findings of this study are summarized in the conceptual model in Figure 4.1 below.

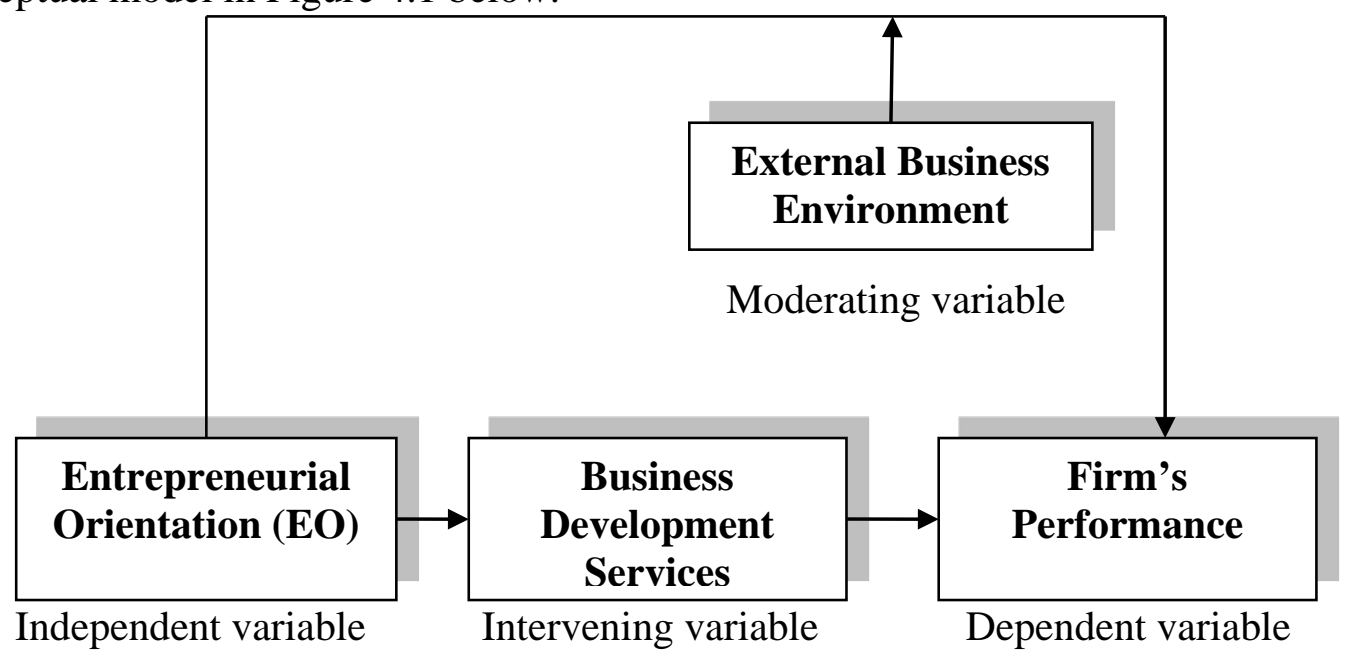

Figure 4.1 - Recommended conceptual model

\section{References:}

1. Atalay, M., Anafarta, N. and Sarvan, F. (2013). The relationship between innovation and firm performance: An empirical evidence 
from Turkish automotive supplier industry. Procedia Social and Behavioural Sciences, 75, 226-236.

2. AEVAL (2008). Evaluation of the Policy for the Improvement of the System of Technology Transfer to the Enterprises, Madrid. Retrieved from http://www.aeval.es/comun/pdf/evaluaciones/E10.pdf. On 9/7/2016

3. Aldrich, H. E. (1979). Organizations and Environments (PrenticeHall, Englewood Cliffs, NJ).

4. Atuahene-Gima, K., and Ko, A. (2001). “An Empirical investigation of the effect of market orientation and entrepreneurial orientation alignment on product innovation,” Organization Science, vol. 12, pp. 54-74, 2001.

5. Avlonitis, G. J. and Salavou, H. E. (2007). Entrepreneurial Orientation of SMEs, ProductInnovativeness, and Performance. Journal of Business Research, 60, 566-575.

6. Awang, A., Ahmad, Z. A., Asghar, A.R.S., and Subari, K.A. (2010). Entrepreneurial Orientation among Bumiputera Small and Medium Agro-based Enterprises in West Malaysia: Policy Implication for Malaysia. International Journal of Business Management Vol. 5 (5) pp 130-143.

7. Baird, I. S. and Thomas, H. (1985). Toward a contingency model of strategic risk taking. Academy of Management Review, 10(2), pp. 230-243.

8. Callaghan, C., and Vente, R. (2011). An investigation of the entrepreneurial orientation, context and entrepreneurial performance of inner-city Johannesburg street traders. Southern African Business Review Volume 15 Number 1, p 28-48

9. Carton, (2004). Measuring organizational performance: an exploratory study. The Journal of American Academy of Business, Cambridge, 68-71.

10. Castrogiovanni, G. J. (1991). 'Environmental Munificence: A Theoretical Assessment', Academy of Management Review, 16, 542-565.

11. Chathoth P.K. (2002). Co-alignment between Environment Risk, Corporate Strategy, Capital Structure, and Firm Performance: An Empirical Investigation of Restaurant Firms. Unpublished Thesis, Virginia Polytechnic Institute and University.

12. Chen, M.J., and Hambrick, D.C. (1995). Speed, stealth and selective attack: How small firms differ from large firms in competitive behavior. Academy of Management Journal, 38: 453-482. 
13. Chen, M.J., Smith, K.G., and Grimm, C. (1992). Action characteristics as predictors of competitive responses. Management Science, 38: 439-455.

14. Covin, J. G., Green, K. M., and Slevin, D. P. (2006). Strategic process effects on the entrepreneurial orientation-sales growth relationship. Entrepreneurship Theory \& Practice, 30(1), 57-81.

15. Coulthard, M. (2007). The Role Of Entrepreneurial Orientation on Firm Performance and the Potential Influence of Relational Dynamism. Journal of Global Business and Technology, 3,29-39

16. Cravens D.W., Shipp S.H., and Cravens K.S. (1993). Analysis of cooperative interorganizational relationships, strategic alliance formation, and strategic alliance effectiveness. Journal of Strategic Marketing, 1, pp. 55-70.

17. Dess, G. G., Lumpkin, G. T., and Covin, J. G. (1997). Entrepreneurial Strategy Making and Firm Performance: Tests of Contingency and Configurational Models. Strategic Management Journal, 18,677-695.

18. Dess, G.G. and Lumpkin, G.T. (2005). The role of entrepreneurial orientation in stimulating effective corporate entrepreneurship. Academy of Management Executive, 19(1), pp. 147-156.

19. Dee,N. J., Livesey, F., Gill, D., and Minshall, T. (2011). Incubation for Growth: A review of the impact of business incubation on new ventures with high growth potential. Retrieved from www.nesta.org.uk on 17th December 2015.

20. Feinstein, O., and Zapico-Goni, E (2010). Evaluation of Government Performance and Public Policies in Spain. ECD Working paper series no. 22. ISBN-13: 978-1-60244-139-2. Retrieved from www.worldbank.org/ieg/ecd on 17th December 2015.

21. Garbrah, T.F.G., and Binfor, F. (2013). Analysis of internal environment of a commercial oriented research organization: Using McKinsey 7S Framework in a Ghanian Context.

International Journal of Academic Research in Business and Social Sciences September 2013, Vol. 3, No. 9 ISSN: 22226990.

22. Goll, I. and Rasheed, A. A. (2004). The Moderating Effect of Business Environmental Munificence and Dynamism on the Relationship between Discretionary Social Responsibility and Firm Performance. Journal of Business Ethics. 49: 41- 54.

23. Gunday, D., Ulusoy, G., Kilic, K., and Alpkan, L. (2007). Effects of innovation types on firm performance. Sabanci University, Istanbul - Turkey. 
24. Giudici A and Reinmoeller P. (2013). Sensing together: an exploration of the support of network intermediaries to firms' and entrepreneurs' search for new opportunities. Unpublished Thesis, Cranfield University.

25. Grimaldi, R. and Grandi, A. (2005). Business incubators and new venture creation: as assessment of incubating models. 'Technovation.' 25: 111-121.

26. Hackett, S. M. and Dilts, D. M. (2004b). A Systematic Review of Business Incubation Research. Journal of Technology Transfer, 29: 55-82.

27. Hamel, G., and Prahalad, C. K. (2005). Strategic intent. Harvard Business Review, 83(7-8), 148-161.

28. Hughes, M. and Morgan, R. E. (2007). Deconstructing The Relationship Between Entrepreneurial Orientation and Business Performance at The Embryonic Stage of Firm Growth. Industrial Marketing Management. 36,651-661.

29. Humprey and Schimtz (1995). Principles of promoting clusters and networks of SMEs. Institute of Development Studies, University of Sussex, U.K.

30. Ireland, R. D, Hitt, M. A., and Sirmon, D. G. (2003). A Model of Strategic Entrepreneurship: The Construct and its Dimensions. Journal of Management, 29(6): 963-89.

31. Iveta, G (2012). Human Resources Key Performance Indicators. Journal of Competitiveness.4 (1), pp 117-128.

32. Kaplan, R. S. and D.P. Norton (2008a). Mastering the Management System," Harvard Business Review (January): 62-57

33. Kaplan, R. S. and D.P. Norton (2008b). The Execution Premium: Linking Strategy to Operations for Competitive Advantage, Boston: HBS Press.

34. Kaplan, R. S. and D.P. Norton (2006a). Alignment: Using the Balanced Scorecard to Create Corporate Synergies, Boston: HBS Press.

35. Kaplan, R. S. and D.P. Norton (2004b). Measuring the Strategic Readiness of Intangible Assets. Harvard Business Review (February): 52-63

36. Kaplan, R.S. (2010). Conceptual Foundations of the Balanced Score Card. Working Paper $10 \quad 074$

37. Kaplan, R. S. and D.P. Norton (1992). The Balanced Scorecard: Measures that Drive Performance. Harvard Business Review, (January-February): 71-79.

38. Keh, H. T., Nguyen, T. T. M. and Ng, H.P. (2007). The effects of entrepreneurial orientation and marketing information on the 
performance of SMEs. Journal of Business Venturing, 22(4), pp. 592-611.

39. Kent, C. A., Sexton, D.L., and Vesper, K.H. (Eds.), Encyclopedia of entrepreneurship: 209 223. Englewood Cliffs, NJ: Prentice Hall.

40. Kenyatta, J. (1965). Africa Socialism and its application in Kenya. Government Printers of Kenya.

41. Kibui, A. W., Gachunga, H., and Namusonge, G.S. (2014). Role of Talent Management on employees retention in Kenya: A survey of state corporations in Kenya: Empirical review.

International Journal of Social Science Vol. 3 (2) pp 414 - 424. ISSN (Online): 2319-7064.

42. Kilby, P. (1971). Hunting the heffalump. In P. Kilby (Ed.), Entrepreneurship and economic development: 1-40. New York: Free Press.

43. Kinyua-Njuguna, J.W., Munyoki, J., and Kibera, F. (2014). Influence of internal organizational environment on performance of community-based HIV and AIDS Organizations in Nairobi County. European Scientific Journal January 2014 edition vol.10, No 1 ISSN: 18577881 (Print) e - ISSN 1857- 7431.

44. Kombo, H.K., K’Obonyo, P., and Ogutu M. (2015). Knowledge Strategy and Performance of Manufacturing Firms in Kenya. Journal of Business \& Economic Policy, Vol. 2, No. 3;

45. Kor, Y.Y. and Mahoney, J.T. (2004). Edith Penroses' (1959) contributions to the Resource based View of Strategic Management. Journal of Management Studies, 41 (1), pp $183 \quad 191$.

46. Kropp, F., Lindsay, N. J. and Shoham, A. (2008). Entrepreneurial Orientation a International Entrepreneurial Business Venture Startup. International Journal of Entrepreneurial

Behaviour \& Research, 14, 102 - I 17.

47. Kusumawardhani, A., McCarthy, G., and Perera, N. (2009). Framework of entrepreneurialorientation and networking: a study of SMEs performance in a developing country. Proceedings of the Australian and New Zealand Academy of Management Conference (pp. 1 16). Adelaide, Australia: Australian and New Zealand Academy of Management.

48. Landstrom, H. (2005). A History of Entrepreneurship and Small Business Research. In Landstrom, H. (Ed.) Pioneers in Entrepreneurship and Small Business Research. Springer Science+Business Media Inc.

49. Lee, C. (2006). Two---warehouse inventory model with deterioration under FIFO dispatching policy. European Journal of Operational Research, Vol. 174, No. 2, pp. 861-873. 
50. Lumpkin G.T., and Dess, G.G. (2001). Linking two dimensions of entrepreneurial orientation to firm performance: The moderating role of environment and industry life cycle. Journal of Business Venturing, 16, 429-451.

51. Lyon, D.W., Lumpkin, G.T., and Dess G.G. (2000). Enhancing entrepreneurial orientation Research: Opeaartionalizing and measuring a key strategic decision making process. Journal of Management, Vol. 26 (5) pp 1055-1085.

52. Maury, B. (2006). Corporate performance, corporate governance and top executive turnover in Finland. European Financial Management, 12(2):221-248.

53. Miles, R. and Snow, C. (1978). Organizational Strategy, Structure and Process. New York, NY. McGraw Hill.

54. Miles, M.P., and Arnold, D.R. (1991). The relationship between marketing orientation and entrepreneurial orientation. Entrepreneurship Theory and Practice, 15: 49-65.

55. Miller, D., and Friesen, P. H. (1982). Innovation in conservative and entrepreneurial firms: two models of strategic momentum. Strategic Management Journal, 3(1), 1-25. doi: 10.1002/smj.4250030102.

56. Miller, D., and Friesen, P. (1978). Archetypes of strategy formulation. Management Science, 24: 921-933.

57. Miller, D., and Friesen, P. (1982). Innovation in conservative and entrepreneurial firms: Two models of strategic momentum. Strategic Management Journal, 3: 1-25.

58. Mintzberg, H. (1973). Strategy making in three modes. California Management Review, 16(2): 44-53.

59. Montanye, J.A. (2006). Entrepreneurship. The Independent Review, $v$. $X, n .4$, Spring 2006, ISSN 1086-1653, pp. 549-571.

60. Miller, D. (2011). 'Miller (1983) revisited: A reflection on EO research and some suggestions for the future'. Entrepreneurship: Theory \& Practice, 35, 873-894.

61. Milovanovic, B.M., and Wittine, Z. (2014). Analysis of External Environment's Moderating Role on the Entrepreneurial Orientation and Business Performance Relationship among Italian Small Enterprises External environment may be hostile. International Journal of Trade, Economics and Finance, Vol. 5, No. 3, June 2014

62. Mitchell, R. K., Smith, B., Seawright, K. W., and Morse, E. A. (2000). Cross-cultural cognitions and the venture creation decision. The Academy of Management Journal, ～43(5), 974993 
63. Morris, M.H., Kuratko, D.F. and Covin, J.G. (2008). Corporate Entrepreneurship \& Innovation. 2nd ed. Mason, OH, USA: Thomson Higher Education.

64. Morris, M. H., Kuratko, D. F., Schindehutte, M., and Spivack, A. J. (2012). Framing the Papasolomou, I., (2006). Can internal marketing be implemented within bureaucratic organizations? International Journal of Bank Marketing, 24, (3), pp. 194-211.

65. Okeyo W. (2015). The interactive nature of business development services in the relationship between external business environment and firm performance. Advances in Social Science Research Journal - Vol 2., No. 2 pp 164 - 177

66. Okeyo W. (2014). The Influence of Business Environmental Dynamism, Complexity and Munificence on Performance of Small and Medium Enterprises in Kenya. International Journal of Business and Social Research (IJBSR), Volume -4, No. 8

67. Okeyo, W., Gathungu, J.M., and K’Obonyo, P. (2014). The Impact of Business Development Services on Entrepreneurial Orientation and Performance of Small and Medium Enterprises in Kenya. International Journal of Business and Social Research (IJBSR), Volume -4, No.- 7

68. Okeyo, W. (2013). Entrepreneurial Orientation, Business Development Services, External Business Environment, Internal Environment, and Performance of SMEs in Kenya. Unpublished PhD Thesis, University of Nairobi School of Business.

69. Odhiambo, L.O. (2015). The relationship between capital structure, performance and replacement of CEOs in forms listed on the Nairobi Securities Exchange. Unpublished PhD Thesis, University of South Africa, School of Business.

70. Patton, D., Warren, L. et al. (2009). Elements that underpin high-tech business incubation processes. Journal of Technology Transfer, 34: 621-636.

71. Pfeffer, J. and Salancik, G. R. (1978). The External Control of Organizations. New York: Happer and Row.

72. Phillips, D.M., and Phillips, J.K. (2012). Buying the Farm: Strategies Young Enterpreneurs Use to Prepare for the Future. The Journal of Applied Management and Entrepreneurship, Vol. 17, No. 4.

73. Piirala, P. (2012). The impact of entrepreneurial orientation on firm performance: a comparative study of Finnish and German SMEs. Unpublished Master's Thesis, Aalto University School of Business.

74. Porter, M. (1980). Competitive Strategy. New York: NY, Free Press. 
75. Porter, Michael E. (1985). Competitive Advantage: Creating and Sustaining Superior Performance, The Free Press, New York, NY, 1985.

76. Rauch, A., Wiklund. J. Lumpkin, G. T. and Frese, M. (2009). Entrepreneurial Orientation and Business Performance: An Assessment and Past Research and Suggestions for the Future. Entrepreneurship Theory and Practice, 33, 761-787.

77. Santos F, and Eisenhardt KM. (2009). Constructing markets and shaping entrepreneurial experience. Entrepreneurship: Theory \& Practice, 36(1), 11-40. boundaries:Entrepreneurial power in nascent field. Academy of Management Journal, 52(4): 643671.

78. Shane, S. and Venkataraman, S. (2000). The promise of entrepreneurship as a field of research. Academy of Management Review, 26(1): 217-226.

79. Tidd, J. (2006). A review of innovation models - discussion paper. Imperial College, London

80. Thugge, K., Ndung'u, J., and Otieno, R.O. (2010). Unlocking the future potential for Kenya -the vision 2030. Retrieved from http://www.csae.ox.ac.uk/conferences/2009 edia/papers/509owino.pdf on 24/9/16

81. UNDP (2004). Business Development Services: How to Guide. Bratislava Regional Center, United Nations Development Programme

82. Wales, W., Monsen, E., and McKelvie, A. (2011). The Organizational Pervasiveness of Entrepreneurial Orientation. Entrepreneurship Theory and Practice, 35(5), pp. 8959923.

83. Walter, A., Auer, M. and Ritter, T. (2006). The impact of network capabilities and entrepreneurial orientation on university spinoff performance. Journal of Business Venturing, 21(4), pp. 541-567.

84. Wiklund, J., and Shepherd, I.D. (2005). "Entrepreneurial orientation and small business performance: A configurational approach," Journal of Business Venturing, vol. 20, pp. 82-83.

85. Wiklund, J. and Shepherd, D. (2011). 'Where to from here? EO-asexperimentation, failure, and distribution of outcomes'. Entrepreneurship: Theory and Practice, 35, 925-946 The Academy of Management Review , 25(1): 217-26.

86. Wiklund, J. and Shepherd, D. (2005). Entrepreneurial orientation and small business performance: a configurational approach. Journal of Business Venturing, 20(1), pp. 7191.

87. Wilson, R.M.S and Gilligan, C., (1997). Strategic Marketing Management: planning, implementation and control, p 256, 2nd Ed. Elsevier Butterworth-Heinemann, UK. 
88. Young, G., Smith, K., and Grimm, C. (1996). “Austrian” and industrial organization perspectives on firm-level competitive activity and performance. Organization Science, 7: 243254.

89. Zahra, S.A., and Covin, J.G. (1995). Contextual influences on the corporate entrepreneurship performance relationship: longitudinal analysis. Journal of Business Venturing, 10: 43-58.

90. Zahra, S., Sapienza, H., and Davidsson, P. (2006). Entrepreneurship and dynamic Capabilities: a review, model and research agenda. Journal of Management Studies, 43, pp. 917-955. 